\title{
Adjustment Mechanism of Major Setup Based on Employment-oriented AEIOU Method*
}

\author{
Zhenyun Zhou ${ }^{1}$, Yongbo Liu ${ }^{2}$, Daoming Wang ${ }^{1}$ and Danqin Ye ${ }^{1}$ \\ ${ }^{1}$ School of Accounting Hangzhou Dianzi University Hangzhou, Zhejiang Province, China \\ ${ }^{2}$ Zhijang College of Zhejiang University of Technology Hangzhou, Zhejiang Province, China \\ zhouzhenyun@hdu.edu.cn, wangdaoming@hdu.edu.cn
}

\begin{abstract}
In order to implement and expanse the colleges' and universities' autonomy of major setup, it is necessary for colleges and universities to improve the internal mechanism to set up and adjust the majors. Based on employment-oriented major setup, this paper elaborates four forces, four types of relationships, as well as five matches which decide major setup. It further illustrates the connotation of the professional orientation, direction, level, scale and structure. The authors build AEIOU method to judge talent demand level and major setup category. Taking 2007-2012 graduates of the School of Accounting at Hangzhou Dianzi University as an example, this thesis proposes major-oriented adjustment mechanism based on the industry demand; professional direction adjustment mechanism based on enterprise talent demand; professional level, scale and structure adjustment mechanism based on employment demand.
\end{abstract}

Index Terms - major setup; employment orientation; AEIOU method; adjustment mechanism

\section{Introduction}

American major setup is closely linked with employment and strong market consciousness, characterized by the colleges and universities which are having independent powers of setting up disciplines. While in China, our major setup and control mechanisms are very imperfect, especially in our colleges and universities, we still have very limited powers of independent setting up disciplines [1]. The professional management mechanism of colleges and universities actively adapting to the demand of social change, self-development and self-adjustment remains to be formed. It is an urgent demand to establish a new system of self-adjustment of the setting and construction of the university disciplines [2].

Then, if colleges and universities want to adapt to the demand of social development, expansion of school autonomy, school characteristic, and improve the quality of personnel training, how to improve the internal mechanism to set and adjust the professional? Employment-oriented major setup is suitable for professional adjustment mechanism based on the characteristics of college talent demand to explore, and it will explore the five aspects of the professional orientation, professional direction, professional-level, professional scale and professional structure.

\section{The Basis of Employment-Oriented Major Setup}

Professional is one of the ties which most closely associated with university and society. It must adapt to the change and the demand of society. Through professional setup and adjustment, we try to seek a balance between demand and response, which requires an effective major setup and control mechanisms [1]. So, how to effectively set major and adjust it?

According to the GUESE model of the employment of graduate [3], we can build the employment-oriented major setup relationship figure which $\mathrm{G}, \mathrm{U}, \mathrm{S}, \mathrm{E}$ stand for Government, University, Student and Enterprise respectively. Figure 1 not only depicts four basic forces which affects major setup, but also describes four basic relationships which determine major setup. At the same time, it shows five basic matches which restrict major setup.

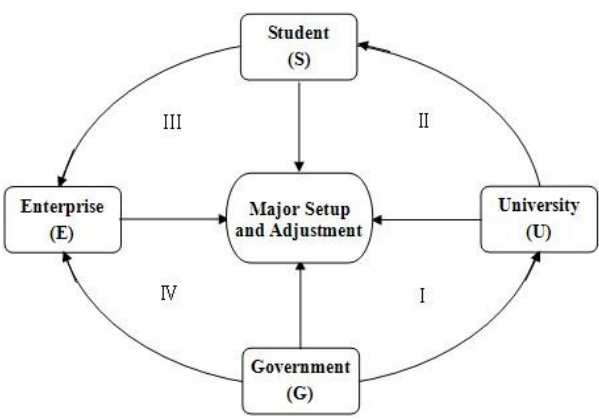

Fig. 1 Relationship of Major Setup and Adjustment

Operating entity of major setup is the four forces, namely, government, university, student and enterprise. Specifically, the reason why major setup dynamically makes adjustment is the comprehensive requirements of the Government to promote the socialization, College training specialization, students becoming personalized, professional enterprise development.

The theoretical basis of the major setup is the four types of relationships which are the relationship between discipline construction equalization( I ) and convergence of major setup (II); the relationship between College Training specialization (II) and professionalization of enterprise positions (III); the relationship between job design immobilized (III) and industrial upgrading dynamics (IV); the relationship between the industrialization of the development of the industry (IV) and disciplinization of education construction (I). The reason why major setup should dynamically adjust is to help defuse the macro contradiction between industrialization of the

\footnotetext{
* This work is mainly supported by XGZD1101 (2011) to Zhenyun Zhou and partially supported by SCG 257(2012) to Zhenyun Zhou.
} 
industry and disciplinization of education. And it also helps crack the microscopic contradiction between business professionalization and school knowledge specialization.

The realistic basis of major setup is the five matches of employment-orientation, which are major setup orientation matching with industrial distribution demand; major setup direction matching with enterprise demand distribution; major setup level matching with the level of position demand; the scale of major setup matching with the scale of position requirements; major setup structure matching with positions demand structure. The reason why major setup should dynamically adjust is that the industries', corporations' and enterprises' adjustment of talent demand is bound to affect the adjustment of the professional regulation of personnel training.

\section{The Connotation of Employment-oriented Major Setup}

Major setup, in a narrow sense, contains professional level, professional scale and professional structure; in a broad sense, includes professional orientation and professional direction.

Professional orientation is determined by the distribution of industries and professions of the talent demand. Distribution of industries and professions refers to the characteristics of the industries' and professions' demand of talents. Professional direction is determined by the talent demand of enterprise distribution, which refers to the characteristics of the business demand of professionals. Professional level is decided by the demand for qualified personnel career levels, which means job demand level category of professionals. Professional scale is decided by the occupational scale, which refers to the total demand of a professional position. Professional structure is decided by occupational structure of the demand for talents. Occupational structure refers to the proportion of demand for various professional positions. The demand discussed above all means effective demand or actual demand.

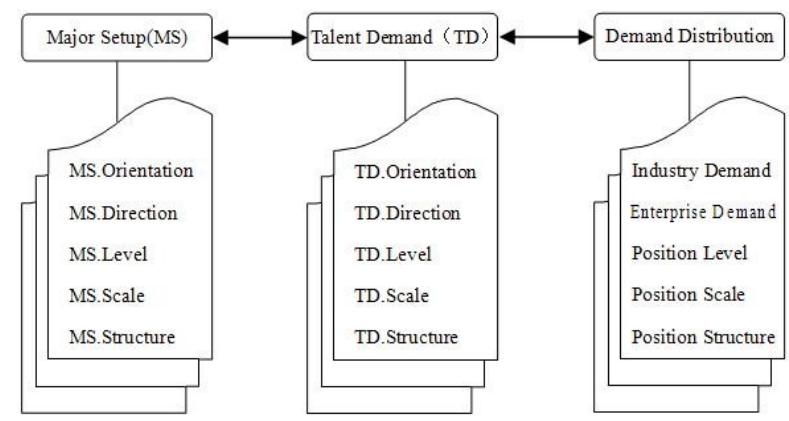

Fig. 2 Match of Major Setup and Talent Demand

The orientation, direction, level, scale and structure of major setup depend on the orientation, direction, level, scale and structure of the demand for talents. Professional orientation is the macro major setup, professional direction is the middle level of major setup, and professional-level, professional scale and professional structure is the microscopic major setup. Major setup and talent demand to match the diagram, as shown in Figure 2.

\section{Employment-oriented AEIOU method}

Figure 2 also shows the judged program of major setup and adjustment. First, investigate and make statistics of related talent demand distribution; second, judge talent demand and major setup; third, carding the dynamic adjustment mechanism of major setup. The judgment of the demand for qualified personnel and major setup refer to level classification of the degree of the actual talent demand and the matching degree of current major setup. According to the talent demand level and major setup category, we can clear the direction for further major setup and adjustment.

TABLE 1 Level Category of Talent Demand and major setup

\begin{tabular}{|c|l|l|}
\hline Code & $\begin{array}{c}\text { Level Category of } \\
\text { Talent Demand }\end{array}$ & $\begin{array}{c}\text { Level Category Of } \\
\text { Major setup }\end{array}$ \\
\hline A & $\begin{array}{l}\text { Absolutely Important } \\
\text { Level Category }\end{array}$ & $\begin{array}{l}\text { Absolutely matched } \\
\text { Level Category }\end{array}$ \\
\hline E & $\begin{array}{l}\text { Especially Important } \\
\text { Level Category }\end{array}$ & $\begin{array}{l}\text { Especially matched } \\
\text { Level Category }\end{array}$ \\
\hline I & $\begin{array}{l}\text { Important } \\
\text { Level Category }\end{array}$ & $\begin{array}{l}\text { Important matched } \\
\text { Level Category }\end{array}$ \\
\hline O & $\begin{array}{l}\text { Ordinary } \\
\text { Level Category }\end{array}$ & $\begin{array}{l}\text { Ordinary matched } \\
\text { Level Category }\end{array}$ \\
\hline U & $\begin{array}{l}\text { Unimportant } \\
\text { Level Category }\end{array}$ & $\begin{array}{l}\text { Unimportant } \\
\text { matched } \\
\text { Level Category }\end{array}$ \\
\hline $\mathbf{X}$ & $\begin{array}{l}\text { Unknown } \\
\text { Level Category }\end{array}$ & $\begin{array}{l}\text { Unknown matched } \\
\text { Level Category }\end{array}$ \\
\hline
\end{tabular}

The AEIOU method is the method for major setup and adjustment judgments. It mainly uses five vowels A, E, I, O and $U$ to characterize the level category of personnel demand and major setup, as shown in Table 1. The level of demand for talents and professional categories respectively refers to talents demand level and major setup category. We noted that AEIOU judged indicators should be set uniformly and relatively reasonable.

TABLE 2 Standard of Talent Demand Level Category

\begin{tabular}{|c|c|c|c|}
\hline $\begin{array}{c}\text { Level } \\
\text { Categor } \\
y\end{array}$ & $\begin{array}{c}\text { Industry } \\
\text { standard }\end{array}$ & $\begin{array}{c}\text { Enterprise } \\
\text { standard }\end{array}$ & $\begin{array}{c}\text { Position } \\
\text { standard }\end{array}$ \\
\hline $\mathrm{A}$ & $\begin{array}{c}\text { proportion greater } \\
\text { than or equal } \\
\text { to } 30 \%\end{array}$ & $\begin{array}{c}\text { talent demand } \\
\text { greater than or } \\
\text { equal to 20 }\end{array}$ & $\begin{array}{c}\text { proportion greater } \\
\text { than or equal } \\
\text { to 30\% }\end{array}$ \\
\hline $\mathrm{E}$ & $\begin{array}{c}\text { proportion greater } \\
\text { than or equal } \\
\text { to } 20 \%\end{array}$ & $\begin{array}{c}\text { talent demand } \\
\text { greater than or } \\
\text { equal to } 15\end{array}$ & $\begin{array}{c}\text { proportion greater } \\
\text { than or equal } \\
\text { to 20\% }\end{array}$ \\
\hline $\mathrm{I}$ & $\begin{array}{c}\text { proportion greater } \\
\text { than or equal } \\
\text { to } 10 \%\end{array}$ & $\begin{array}{c}\text { talent demand } \\
\text { greater than or } \\
\text { equal to } 10\end{array}$ & $\begin{array}{c}\text { proportion greater } \\
\text { than or equal } \\
\text { to } 10 \%\end{array}$ \\
\hline $\mathrm{O}$ & $\begin{array}{c}\text { proportion greater } \\
\text { than or equal } \\
\text { to } 8 \%\end{array}$ & $\begin{array}{c}\text { talent demand } \\
\text { greater than or } \\
\text { equal to 5 }\end{array}$ & $\begin{array}{c}\text { proportion greater } \\
\text { than or equal } \\
\text { to 5\% }\end{array}$ \\
\hline $\mathrm{U}$ & $\begin{array}{c}\text { proportion greater } \\
\text { than or equal } \\
\text { to 3\% }\end{array}$ & $\begin{array}{c}\text { talent demand } \\
\text { greater than or } \\
\text { equal to 3 }\end{array}$ & $\begin{array}{c}\text { proportion greater } \\
\text { than or equal } \\
\text { to } 1 \%\end{array}$ \\
\hline $\mathbf{X}$ & $\begin{array}{c}\text { Proportion } \\
\text { Less than } \\
3 \%\end{array}$ & $\begin{array}{c}\text { talent demand } \\
\text { less than }\end{array}$ & $\begin{array}{c}\text { Proportion } \\
\text { Less than } \\
1 \%\end{array}$ \\
\hline
\end{tabular}

So, how to judge the demand for talents level? In a different distribution of personnel demand, absolute 
percentage, the relative percentage, the absolute value or relative value can be used as judged basis. Table 2 is a reference to the below and is the judged basis for distribution of the demand for qualified personnel of industry, businesses and jobs. And major setup categories can be judged by whether setting courses match with the demand for talents distribution characteristics. And these courses include specialist course group, required courses, limited choice of courses, public election and optional courses. The judgment can define A, E, I, O, U and X level category of the current major setup.

\section{Adjustment Mechanism of Accounting Major Setup}

A. Profession-oriented adjustment mechanism based on the industry demand

\section{1) Industrial demand for talents}

Employment-oriented, the industrial industry demand can determine the professional orientation. Specifically, the distribution of industrial industry demand can decide the major setup orientation. According to the three industries zoning regulations promulgated by the State General Administration of Quality Supervision, Inspection and Quarantine and the National Standards Commission national industry classification "(GB / T 4754-2011) and the National Bureau of Statistics revised in 2012 [4], taking 2007-2012 graduates of the School of Accounting at Hangzhou Dianzi University as an example, we can determine the distribution of industry demand for accounting talents.

\section{2) Judgment of industry demand for talents}

According to the talent demand of the top five industries and professions and the AEIOU judged table, we can determine the level of demand for industries and professions. The industry standard of Table 2 and the judged indicators of Table 6 all use relative proportion; the base of relative proportions refers to the total number of the top five industry talent demand in the past years. This demand has accounted for a total of $76.92 \%$ of the total number of graduates over the years. Industry demand distribution is concentrated, and the demand level is evident. Business services (L), manufacturing (C), the financial sector $(\mathrm{J})$, the demand for education $(\mathrm{P})$ and public administration (S) level are respectively short for the A, $\mathrm{E}, \mathrm{I}, \mathrm{I}$ and $\mathrm{O}$.

How to judge categories of major setup based on the needs of the industries and professions? We can judge whether the existing major setup match with industry demand level, and whether professional courses match with the demand of the industrial and professional orientation. Thereby, as is shown in Table 3, the existing major setup level category which corresponds to the demand of the top five Industries are respectively E, I, $\mathrm{U}, \mathrm{O}$, and $\mathrm{U}$.

\section{3) Profession-oriented adjustment mechanism}

Contrasting demand level and setup categories in Table 4, we will provide profession-oriented adjustment mechanism based on industries' and professions' demand for major setup. In the aspect of major setup and orientation of adjustment, it should match with the distribution characteristics of industries' and professions' talent demand, and give priority to the implementation of the business services (L) personnel training framework. It should focus on the implementation of the manufacturing industry (C) personnel training framework, expedite the implementation of the financial sector $(\mathrm{J})$ personnel training outline, steadily implement the education of personnel training framework (P) and orderly implement public administration of personnel training framework $(\mathrm{S})$.

TABLE 3 Analysis of AEIOU on Industry

\begin{tabular}{|c|c|c|c|c|}
\hline $\begin{array}{c}\text { Industry and } \\
\text { Level Category }\end{array}$ & $\begin{array}{c}2007- \\
2012\end{array}$ & $\begin{array}{c}\text { Index } \\
(\%)\end{array}$ & $\begin{array}{c}\text { Talent } \\
\text { Demand }\end{array}$ & $\begin{array}{c}\text { Major } \\
\text { Setup }\end{array}$ \\
\hline $\begin{array}{c}\text { Business Services } \\
(\mathrm{L})\end{array}$ & 439 & 32.52 & $\mathrm{~A}$ & $\mathrm{E}$ \\
\hline $\begin{array}{c}\text { Manufacturing } \\
(\mathrm{C})\end{array}$ & 328 & 24.30 & $\mathrm{E}$ & $\mathrm{I}$ \\
\hline $\begin{array}{c}\text { Financial Sector } \\
(\mathrm{J})\end{array}$ & 258 & 19.11 & $\mathrm{I}$ & $\mathrm{U}$ \\
\hline $\begin{array}{c}\text { Education } \\
(\mathrm{P})\end{array}$ & 191 & 14.15 & $\mathrm{I}$ & $\mathrm{O}$ \\
\hline $\begin{array}{c}\text { Public Administration } \\
\text { (S) }\end{array}$ & 134 & 9.93 & $\mathrm{O}$ & $\mathrm{U}$ \\
\hline
\end{tabular}

B. Professional direction adjustment mechanism based on the enterprises' talent demand

1) Enterprise demand for talents

Based on employment orientation, enterprise demand determines the professional direction. In other words, enterprise demand distribution determines the direction of major setup. Pan-China Certified Public Accountants (Tianjian), Hangzhou Dianzi University (Hangdian), SHU LUNPAN Certified Public Accountants (Lixin), Bank of China (BC), and Local Rural cooperative banks (rural banks) are the top five enterprises which demand talents most.

2) Judgment of enterprise demand for talents

According to the talent demand of the top five enterprises and talent demand AEIOU judged standard tables, we can determine the level of demand of enterprises. Enterprise standards in Table 2 and judged indicators in Table 4 all use the number of graduates of the enterprise average annual demand for the Hang electricity accounting class. Therefore judged, Tianjian, Hangdian, Lixin, $\mathrm{BC}$ and rural banks demand level are A, I, I, O and O respectively. Demand of the top ten enterprises in turn are the IMC accounting firm, $\mathrm{ABC}, \mathrm{CBC}$, ICBC, and in exchange accounting firm. This shows that the two major categories of enterprise business servicesaccounting firms and banking institutions in the financial sector are very important to the demand for talents in Hangzhou Dianzi University of Accountancy.

How to judge it when based on the business needs of major setup category? We can judge by seeing to what extent is the existing major setup matching with industry demand level and to what extent is the current professional curriculum matching with the direction of the demand of enterprises. Therefore judged, as is shown in table 4, the corresponding existing major setup level category of the demand of the top five companies are $\mathrm{E}, \mathrm{O}, \mathrm{O}, \mathrm{U}$, and $\mathrm{U}$ respectively. 
TABLE 4 Analysis of AEIOU on Enterprise

\begin{tabular}{|c|c|c|c|c|}
\hline $\begin{array}{c}\text { Enterprise and } \\
\text { Level Category }\end{array}$ & $\begin{array}{c}2007- \\
2012\end{array}$ & $\begin{array}{c}\text { Analysi } \\
\text { Index }\end{array}$ & $\begin{array}{c}\text { Talent } \\
\text { Demand }\end{array}$ & $\begin{array}{c}\text { Major } \\
\text { Setup }\end{array}$ \\
\hline $\begin{array}{c}\text { Pan-China Certified } \\
\text { Public Accountants }\end{array}$ & 135 & 22.5 & $\mathrm{~A}$ & $\mathrm{E}$ \\
\hline $\begin{array}{c}\text { Hangzhou Dianzi } \\
\text { University }\end{array}$ & 75 & 12.5 & $\mathrm{I}$ & $\mathrm{O}$ \\
\hline $\begin{array}{c}\text { SHU LUNPAN Certified } \\
\text { Public Accountants }\end{array}$ & 64 & 10.7 & $\mathrm{I}$ & $\mathrm{O}$ \\
\hline Bank of China & 30 & 5 & $\mathrm{O}$ & $\mathrm{U}$ \\
\hline Rural cooperative banks & 30 & 5 & $\mathrm{O}$ & $\mathrm{U}$ \\
\hline
\end{tabular}

\section{3) Professional direction adjustment mechanism}

Comparing the demand level and setup categories in table 4 , we will provide major setup with professional direction adjustment mechanism based on enterprise talent demand. In the aspect of major setup and the direction of adjustment, it should match with the distribution characteristics of the enterprise talent demand, and give priority to the determination of the Tianjian and Lixin accounting firm personnel training guide; it should focus on the determination that the personnel training guide of Hangzhou Dianzi University cooperating with British University of Glasgow for further studies abroad; it should accelerate the decision of the personnel training guide of banking institutions such as Chinese banks and rural banks.

\section{Professional level, scale and structure adjustment} mechanism based on the demand for professional positions

1) Professional positions for talents demand

Under the circumstance of employment orientation, job demand determines the professional structure, scale and level. In other words, the job demand structure determines the structure of major setup, the scale of the job demand determines the scale of major setup, and job demand level determines the level of major setup. Table 5 is the table of talent demand job distribution, and the statistics based on the nature and the social demand characteristics of the occupational status of the accounting position. In particular, the recruitment positions refer to the institutions recruiting position such as financial banking, graduate studies, study abroad and government organizations.

Other jobs refer to the situation that one is waiting for job or inter-professional employment.

\section{2) Judgment of positions demand for talents}

According to the distribution tables of the demand for qualified personnel positions and personnel demand AEIOU judged standard table, we can determine the level of job demand. Post-Standard in table 2 and judged indicators in table 5 all use absolutely proportion; the absolute ratio base refers to the total number of graduates over the years. Looking at the demand level of the job requirements, accounting positions and recruit posts are A; demand level of audit jobs and financial positions are respectively $\mathrm{E}$ and I; and other posts are U.

How can we judge it when professional setup categories are based on the demand for professional positions? It can be judged by seeing whether the existing major setup matching with job demand level; whether courses matching with positions demand mutually. Job requirements are not only related with the hierarchy of demand, but also related with the scale and structure of demand. Therefore judged, as is shown in table 5, the corresponding existing level of major setup categories to the demand for talents ranking the top five positions are $\mathrm{A}, \mathrm{U}, \mathrm{I}, \mathrm{I}$, and $\mathrm{U}$ respectively.

TABLE 5 Analysis of AEIOU on Position

\begin{tabular}{|l|c|c|c|c|}
\hline $\begin{array}{c}\text { Position and } \\
\text { Level Category }\end{array}$ & $\begin{array}{c}2007- \\
2012\end{array}$ & $\begin{array}{c}\text { Index } \\
(\%)\end{array}$ & $\begin{array}{c}\text { Talent } \\
\text { Demand }\end{array}$ & $\begin{array}{c}\text { Major } \\
\text { Setup }\end{array}$ \\
\hline Accounting Position & 615 & 35.04 & $\mathrm{~A}$ & $\mathrm{~A}$ \\
\hline Recruitment Position & 549 & 31.28 & $\mathrm{~A}$ & $\mathrm{U}$ \\
\hline Audit Position & 352 & 20.06 & $\mathrm{E}$ & $\mathrm{I}$ \\
\hline Finance Position & 206 & 11.74 & $\mathrm{I}$ & $\mathrm{I}$ \\
\hline Other Position & 33 & 1.88 & $\mathrm{U}$ & $\mathrm{U}$ \\
\hline
\end{tabular}

3) Professional level, scale and structure adjustment mechanism

Comparing the level of demand and set up categories in table 5, we will provide major setup with professional level, professional scale and professional structure adjustment mechanism based on the demand for professional positions. In the aspect of major setup and adjustment, the professional level, scale and structure should match with the talent demand of professional positions to optimize the implementation of accounting positions personnel training programs, to promote the implementation of the plans of recruiting job personnel training, to expand the implementation of the audit job personnel training plan and to adjust the implementation of the financial positions personnel training plan.

\section{Acknowledgment}

This work is mainly supported by XGZD1101 to Zhenyun Zhou through Higher Education Research Subject of Hangzhou Dianzi University in 2011, and partially supported by SCG257 to Zhenyun Zhou through Education Scientific Planning Research Subject of Zhejiang Research Institute of Education Science in 2012.

\section{References}

[1] Yang Rongwei. Colleges' major setup and regulation of research . Shanghai: East China Normal University, Graduate School of, 2006:2 -8.

[2] Fu Jinjun, Jin Yuehua. Scientific concept of development guides the adjustment university personnel training structure. Hangzhou University of Electronic Technology (Social Science), 2007, 3 (2):53-56.

[3] Zhou Zhenyun, Wang Jingjing, Thought on Construction. Difficult employment of college students' model analysis and countermeasures. Hangzhou University of Electronic Technology (Social Science Edition), 2011, 7 (3):75-78.

[4] National Bureau of Statistics of the People's Republic of China. Division of three industries requires [EB / OL] http://www.stats.gov.cn/ tjbz/ t20130114_402865889.htm, 2013-01-14. 